Contract No. and Disclaimer:

This manuscript has been authored by Savannah River Nuclear Solutions, LLC under Contract No. DE-AC09-08SR22470 with the U.S. Department of Energy. The United States Government retains and the publisher, by accepting this article for publication, acknowledges that the United States Government retains a non-exclusive, paid-up, irrevocable, worldwide license to publish or reproduce the published form of this work, or allow others to do so, for United States Government purposes. 


\title{
Characterization of modified monosodium titanate - an improved sorbent for strontium and actinide separations
}

\author{
Kathryn M. L. Taylor-Pashow, D. M. Missimer, A. Jurgensen, \\ and D. T. Hobbs*
}

Savannah River National Laboratory

Aiken, SC 29808

\begin{abstract}
High-level nuclear waste produced from fuel reprocessing operations at the Savannah River Site (SRS) requires pretreatment to remove ${ }^{134,137} \mathrm{Cs},{ }^{90} \mathrm{Sr}$, and alphaemitting radionuclides (i.e., actinides) prior to disposal onsite as low level waste. An inorganic sorbent, monosodium titanate (MST), is currently used to remove ${ }^{90} \mathrm{Sr}$ and alpha-emitting radionuclides, while a caustic-side solvent extraction process is used for removing ${ }^{134,137}$ Cs. A new peroxotitanate material, modified MST, or mMST, has recently been developed and has shown increased removal kinetics and capacity for ${ }^{90} \mathrm{Sr}$ and alpha-emitting radionuclides compared to the current baseline material, MST. This paper describes recent results focused on further characterization of this material.
\end{abstract}

Key words: ion exchange, peroxotitanate, plutonium, neptunium, uranium, alkaline waste, iodometric titration

Short Title: Modified Monosodium Titanate

*corresponding author 


\section{INTRODUCTION}

Monosodium titanate (MST) is an inorganic sorbent material that exhibits high selectivity for strontium and actinide elements in the presence of strongly alkaline and high sodium containing salt solutions. This material currently serves as the baseline sorbent for the removal of ${ }^{90} \mathrm{Sr}$ and alpha-emitting radionuclides from $\mathrm{HLW}$ at the Savannah River Site (SRS). ${ }^{[1-5]}$ Efforts to increase efficiency and rapidly remove alphaemitting radionuclides to increase operational throughput led to the identification of a peroxotitanate material with improved strontium and actinide removal characteristics. ${ }^{[6]}$

Compared to the baseline MST material, the new peroxotitanate material, referred to as modified MST, or mMST, exhibits higher batch (short-term) capacities and kinetics for the separation of strontium and actinides from alkaline waste solutions. ${ }^{[6-8]}$ Consequently, this material offers the opportunity to reduce sorbent use and increase throughput in processing facilities. Previous publications described the optimization of synthetic conditions and performance testing under a variety of conditions. ${ }^{[6-9]}$ This paper describes recent results focused on further characterization of the material, including gas release during synthesis and storage, settling characteristics, peroxide content, and solid phase transformations upon heating to elevated temperatures.

\section{EXPERIMENTAL}

\section{Preparation of MST and mMST}

The MST used in these studies was prepared using a sol-gel process developed at the Savannah River National Laboratory (SRNL) and supplied by Optima Chemical Group LLC (Douglas, GA, Lot \#00-QAB-417) as a $15 \mathrm{wt} \%$ suspension in water

containing 0.10-0.15 $\mathrm{M} \mathrm{NaOH}$ and 100-150 $\mathrm{mg} \mathrm{L}^{-1} \mathrm{NaNO}_{2} \cdot{ }^{[4]}$ Modified monosodium 
titanate (mMST) used in these studies was prepared by the post-synthesis treatment of MST with hydrogen peroxide. The details of this procedure have been previously published. ${ }^{[6]}$ Bench-scale quantities of mMST were prepared using 25 grams of the Optima-supplied MST. Optima Chemical Group LLC (Douglas, GA) also produced a pilot-scale quantity $(15 \mathrm{~kg})$ of mMST, Lot \#06-QAB-0139, as a $15 \mathrm{wt} \%$ suspension in water using the same conditions as used for the bench-scale preparations.

Six small-scale batches of mMST were also synthesized with varying hydrogen peroxide:Ti ratios, $0.25: 1,0.5: 1,1: 1,2: 1,3: 1$, and $4: 1$, for characterization of peroxide content. Earlier development of mMST lead to the choice of $3: 1$ as the optimal $\mathrm{H}_{2} \mathrm{O}_{2}: \mathrm{Ti}$ ratio, ${ }^{[6]}$ and this ratio was used for the synthesis of the commercial scale batch of mMST (Optima 06-QAB-0139), and other larger, bench-scale (25-gram) prepared samples. These mMST samples were synthesized by adding the appropriate amount of a $30 \mathrm{wt} \%$ solution of hydrogen peroxide dropwise to approximately $10 \mathrm{~g}$ of a $15 \mathrm{wt} \%$ suspension of baseline MST (Optima 00-QAB-417). The MST had been previously isolated and washed, and the washed MST was then dispersed in water. The $\mathrm{pH}$ of the MST suspension was adjusted to 7 before the addition of peroxide. After the peroxide addition was complete, the reactions were stirred at room temperature for 24 hours. The products were then isolated by centrifuging $(1400 \mathrm{x}$ g for $15 \mathrm{~min})$ and were washed six times with distilled water. After the final wash, the mMST samples were dispersed in water, and the $\mathrm{pH}$ of each suspension was adjusted to 4 with $1 \mathrm{M}$ nitric acid. The suspensions were diluted to a final mass of approximately $10 \mathrm{~g}$, and the weight percentage solids were determined. 


\section{Gas Release Measurements}

During the synthesis of a $25-\mathrm{g}$ batch of the mMST two gas samples were collected during the addition of the hydrogen peroxide. Gas samples were collected by locating a glass sampling bulb between the reactor and the bubbler such that any gases formed pass through the sample bulb before venting to the atmosphere through the bubbler. The glass sampling bulb was then isolated from the system. Identification and quantification of the gas composition utilized gas chromatography.

To evaluate the quantity and time-dependent behavior for the formation of gases after the synthesis, a test chamber was constructed consisting of a cylindrical plastic tube, a glass U-tube filled with ultrapure water and a gas-tight syringe. The cylindrical plastic tube was filled with a freshly prepared $25-\mathrm{g}$ batch of mMST as a $15 \mathrm{wt} \%$ suspension in water. The system was closed to the atmosphere so that any gas produced and released to the vapor space displaced water in the attached U-tube. The volume of displaced liquid was measured periodically by pulling the released gas into a gas-tight $1.0-\mathrm{mL}$ syringe, which returns the liquid level to the original position in the U-tube. After recording the volume, the system was vented to the atmosphere and then closed again. Time intervals were recorded between each set of measurements.

Over the course of the experiment, gas accumulated in the slurry resulting in an overall increase in the height of the suspension. Periodically, the walls of the cylindrical tube were gently tapped to release this trapped gas. In addition to releasing trapped gas, tapping also suspends some fraction of the settled solids. Over the course of the experiment, the system was opened once and the contents of the cylindrical tube were 
mixed with a stainless steel rod to re-suspend the solids. After mixing, the system was again closed and gas release measurements continued.

Similar experiments were also performed using samples of mMST that were washed with acidic or basic solution during the work-up of the reactions. In contrast, the normal work-up involves isolation of the material by filtration followed by washing with distilled water.

An additional gas release experiment was also performed at elevated temperature, $49^{\circ} \mathrm{C}$, to determine the gas release rates that may be observed during shipping and storage of the material. For this experiment, the cylindrical plastic tube described above was replaced with a round bottom flask. The flask was then submerged in a temperature controlled water bath for the course of the experiment.

\section{Solids Settling Characteristics}

The settling characteristics of the baseline and modified MST were measured in aqueous solutions over a range of $\mathrm{pH}$ values. The baseline and modified MST suspensions used in this test were the commercially prepared Optima Batch \#00-QAB417 and Optima Batch \#06-QAB-0139, respectively. The $\mathrm{pH}$ of the as-received baseline and modified MST suspensions measured 10.47 and 4.84, respectively. Suspensions of each MST sample were prepared at $\mathrm{pH}$ values of $6,7,8,9$ and 10 by adding $2 \mathrm{M}$ nitric acid solution to the baseline MST suspension and $2 \mathrm{M} \mathrm{NaOH}$ solution to the modified MST suspension. After mixing for 30 minutes, aliquots of approximately $11 \mathrm{~mL}$ were transferred from each of the as-received and $\mathrm{pH}$-adjusted suspensions into separate 15$\mathrm{mL}$ glass centrifuge tubes. The suspensions then stood at ambient laboratory temperature 
undisturbed for 50 days. Each tube was periodically inspected and the height of the settled solids was measured.

Two tests were also performed to examine the settling characteristics of mMST in simulated salt solutions, with sodium concentrations of $0.5,4.6,5.6$, and $6.6 \mathrm{M}$. The first test involved determination of the settled solids density. For this experiment, aliquots of mMST (Optima 06-QAB-0139) were added to $15-\mathrm{mL}$ centrifuge tubes. The solids were washed once with the appropriate salt solution (5 mL), either SWS-11-2008 (5.6 M Na) or SWS-12-2008-2 (0.5 M Na), and were re-isolated by centrifugation at $1400 \mathrm{x} g$ for 2 minutes. After decanting the solution, $10-\mathrm{mL}$ aliquots of the salt solutions were added to the washed solids. The contents were then gently mixed to suspend all the solids. Each suspension was then centrifuged at either $6.3 \mathrm{x} g$ or $1400 \mathrm{x} g$ for 10 minutes. The volume of the settled solids was then measured. Without disturbing the settled solid plug in the bottom of the centrifuge tube, the tube was returned to the centrifuge, and was centrifuged for an additional 5 minutes at the appropriate speed. The tubes were removed and the volume of settled solids was again measured. This process was repeated until no additional change in the settled solids volume occurred.

The second set of tests examined the solid settling rate as a function of time in three salt solutions with $\mathrm{Na}$ concentrations of 4.6, 5.6, and $6.6 \mathrm{M}$. For these experiments aliquots of mMST and MST were placed in graduated cylinders along with $90 \mathrm{~mL}$ of the appropriate salt solutions, giving final mMST/MST concentrations of $0.53 \mathrm{~g} / \mathrm{L}$. Each cylinder was capped, and shaken to disperse the solids. The graduated cylinders were then placed on the bench top, and the level of the liquid-solid interface was monitored as a function of time. During the tests two interfaces were observed, one between the 
cloudy slurry and the clear supernate at the top which is indicative of the smallest, slowest settling particles (fines), and one between the concentrated slurry and cloudy slurry located at the bottom of the graduated cylinder. This bottom interface is indicative of the largest fastest settling particles.

\section{High Temperature X-Ray Diffraction Analyses (HTXRD)}

X-ray diffraction data (XRD) were collected on a theta-theta PANalytical X'Pert Pro X-ray diffractometer using an Anton Paar HTK 1200 high temperature attachment. Instead of fixing the sample on a resistively heated platinum strip, the sample cup was placed in a uniformly heated sample chamber in the camera. A type S thermocouple was inserted into the chamber near the sample cup to monitor the sample temperature. This configuration eliminates most of the sample temperature gradients observed in ribbon style high temperature attachments. The alumina sample cup has a well that is $0.4 \mathrm{~mm}$ deep. The instrument was scanned over a $5-70^{\circ} 2 \theta$ range with a $0.0167^{\circ}$ step size and a dwell time of $99.695 \mathrm{~s} / 2.122^{\circ}(2 \theta)$ for a total measurement time of $\sim 25$ minutes. The large dwell time with short analysis time was achieved using the $\mathrm{X}^{\prime}$ Celerator ${ }^{\mathrm{TM}}$ detector $^{\circ}$ that has a $2.122^{\circ}(2 \theta)$ active length and operates as if there were an array of over a hundred detectors working simultaneously. High temperature X-ray diffraction scans were performed at seven temperatures, $25,75,125,250,300,600$, and $800{ }^{\circ} \mathrm{C}$. All the HTXRD scans were performed under an ultra-pure $(>99.999 \%)$ helium purge. After the powder sample had cooled to room temperature, the powder residue was ground into a fine powder and analyzed using a conventional XRD arrangement. A detailed compilation of all the instrument parameters is included in the Supplemental Information 
Table 1S. Compound search-match identification was performed with Jade ${ }^{\mathrm{TM}}$ software (Version 9) from Materials Data Inc. using the latest inorganic PDF4 ${ }^{\mathrm{TM}}$ powder diffraction database from the International Centre for Diffraction Data (ICDD).

A temperature calibration curve was generated for the helium atmosphere to correct for any temperature gradients in the high temperature attachment and any thermal lag between the measured and set-point temperatures. The phase transition temperatures and melting points for several recommended compounds routinely referenced by the Xray diffraction community were used to construct calibration curves for He. ${ }^{[10-11]}$ The observed temperatures were $\sim 4-30{ }^{\circ} \mathrm{C}$ low in helium with the smallest $\Delta \mathrm{T}$ at low temperatures. All the temperature data were corrected.

Two samples of both baseline and modified MST were analyzed. The first two samples were the commercially prepared materials as received (Optima 00-QAB-417 and Optima 06-QAB-0139). The second two samples were samples of these commercially prepared batches that had been $\mathrm{pH}$ adjusted. The baseline MST is received as a $\mathrm{pH} 10$ slurry and the mMST is received as a $\mathrm{pH} 4$ slurry. For the HTXRD experiments samples of MST were adjusted to $\mathrm{pH} 4$ and samples of mMST were adjusted to $\mathrm{pH} 10$. All samples were dried prior to analysis.

\section{Iodometric Titrations}

Iodometric titrations were performed using several modified MST samples. The general procedure for the titrations involved first performing the reaction between sodium iodide and peroxide to form iodine, which was then titrated with sodium thiosulfate using starch as an indicator (see reactions 1 and 2). An aliquot of a known weight percent 
suspension of mMST was placed in a $25-\mathrm{mL}$ volumetric flask. The amount of suspension added corresponded to between 0.3 and $0.4 \mathrm{~g}$ of mMST. The suspension was then diluted to an approximate volume of $15-20 \mathrm{~mL}$ with distilled water. Then $0.42 \mathrm{~mL}$ of $18 \mathrm{M}$ sulfuric acid was added to the suspension, and the sample was diluted to the $25-\mathrm{mL}$ mark with additional distilled water. This suspension was then transferred to a glass vessel containing a stir bar, and $25 \mathrm{~mL}$ of a $0.27 \mathrm{M}$ solution of sodium iodide was added. This reaction was then stirred at room temperature for a minimum of 17 hours. Aliquots of the reaction mixture were then removed and titrated with a $0.1 \mathrm{M}$ solution of sodium thiosulfate, using starch as an indicator. All titrations were performed in triplicate.

$$
\begin{aligned}
& \mathrm{H}_{2} \mathrm{O}_{2}+2 \mathrm{I}^{-}+2 \mathrm{H}^{+} \rightarrow \mathrm{I}_{2}+2 \mathrm{H}_{2} \mathrm{O} \\
& 2 \mathrm{Na}_{2} \mathrm{~S}_{2} \mathrm{O}_{3}+\mathrm{I}_{2} \rightarrow \mathrm{Na}_{2} \mathrm{~S}_{4} \mathrm{O}_{6}+2 \mathrm{NaI}
\end{aligned}
$$

Control experiments were also performed without any material, i.e. just sulfuric acid and sodium iodide, and also with baseline MST, which contains no peroxide. No measurable amount of $\mathrm{I}_{2}$ was formed in the blank control experiment; however, the baseline MST did cause the formation of iodine from $\mathrm{NaI}$ under the reaction conditions. Experiments were also performed using the supernatant from mMST and MST slurries, and also dried samples of MST. The results from the supernatant titrations indicated no formation of $I_{2}$ from the mMST supernatant. Reaction of the MST supernatant did lead to the formation of $I_{2}$, while the dried sample of MST did not. The formation of $I_{2}$ in the MST supernatant experiment is due to the presence of $\mathrm{NaNO}_{2}$ added to the commercially prepared MST as a corrosion inhibitor (see reaction 3).

$$
2 \mathrm{HNO}_{2}+2 \mathrm{H}^{+}+2 \mathrm{I}^{-} \rightarrow \mathrm{I}_{2}+2 \mathrm{NO}+2 \mathrm{H}_{2} \mathrm{O}
$$




\section{Affect of Alkaline Solution on Peroxide Content}

A series of experiments were also performed to determine how much of the peroxide was lost upon exposure to alkaline salt solutions, such as the simulated waste solutions used for performance testing. For these experiments, aliquots of mMST suspension (Optima Batch 06-QAB-0139), corresponding to $0.10 \mathrm{~g}$ of mMST solid, were added to $500 \mathrm{~mL}$ volumes of several salt solutions. The mixtures were then stirred at room temperature for 24 hours. The mMST solids were isolated by filtration through a $0.2-\mu \mathrm{m}$ membrane, and were washed three times with distilled water. The washed solids were then transferred to a 10 -mL volumetric flask. The solids were dispersed in water, $0.42 \mathrm{~mL}$ of $18 \mathrm{M}$ sulfuric acid was added, and the mixture was diluted to a final volume of $10 \mathrm{~mL}$. This suspension was then transferred to a glass vessel containing a stir bar, and $10 \mathrm{~mL}$ of a $0.27 \mathrm{M}$ solution of sodium iodide was added. This reaction was then stirred at room temperature for a minimum of 17 hours. 6-mL aliquots of the reaction mixture were then removed and titrated with a $0.1 \mathrm{M}$ solution of sodium thiosulfate, using starch as an indicator. All titrations were performed in triplicate. The three solutions tested included SWS-1-2010, a non-radioactive salt solution containing only sodium, SWS-1-2008, a non-radioactive salt solution containing Sr, and a control experiment using distilled water. The compositions of the salt solutions are presented in Table 1.

\section{Affect of Age on mMST Performance}

Iodometric titration analyses indicated that the peroxide content of modified MST samples decreases linearly with age. Sr and actinide sorption tests were performed with several lab prepared batches of mMST of varying age (see Table 2). Performance tests 
were carried out with a simulated waste solution (SWS-9-2009) having the composition shown in Table 3. $60-\mathrm{mL}$ aliquots of this simulant were placed in 125-mL HDPE bottles. After equilibrating at $25^{\circ} \mathrm{C}$, overnight, aliquots of mMST were added, giving final mMST concentrations of $0.2 \mathrm{~g} / \mathrm{L}$. The experiments were carried out in a waterbath/shaker at $25^{\circ} \mathrm{C}$, with an agitation speed of $175 \mathrm{rpm}$. Samples were taken after 6,12 , and 24 hours of contact, and were filtered through a 0.1- $\mu \mathrm{m}$ PVDF filter. The samples were then acidified before being submitted for analysis of $\mathrm{Sr}, \mathrm{U}, \mathrm{Np}$, and $\mathrm{Pu}$ content using ICP-MS, gamma scan, and PuTTA analyses.

Previous testing indicated that the mMST does not adsorb appreciable uranium, as opposed to MST, which does. ${ }^{[8]}$ A performance test was designed using a uranium only simulant to examine if the loss of peroxide with age causes the mMST to begin sorbing uranium. Performance tests were carried out with simulated waste solution (SWS-82007) having the composition shown in Table 3. $60-\mathrm{mL}$ aliquots of this simulant were placed in $125-\mathrm{mL}$ HDPE bottles. After equilibrating at $25^{\circ} \mathrm{C}$, overnight, aliquots of MST (Optima Batch 00-QAB-417) and mMST (Optima Batch 06-QAB-0139) were added, giving final sorbent concentrations of $3.0 \mathrm{~g} / \mathrm{L}$. The experiments were carried out in a waterbath/shaker at $25^{\circ} \mathrm{C}$, with an agitation speed of $175 \mathrm{rpm}$. Samples were taken after 4 and 12 hours of contact, and were filtered through a $0.1 \mu \mathrm{m}$ PVDF filter. The samples were then acidified before being submitted for analysis of U content using ICPMS.

\section{RESULTS AND DISCUSSION}

Gas Release from mMST 
During the synthesis of mMST, gas bubbles are readily formed during and after the addition of the hydrogen peroxide. To identify the composition of the gas formed during synthesis two gas samples were collected during the addition of the hydrogen peroxide. Gas Sample \#1 was collected from the beginning of the hydrogen peroxide addition and up until one-half of the hydrogen peroxide had been added to the reaction flask. Gas Sample \#2 was collected during the second half of the hydrogen peroxide addition. Both gas samples were analyzed in duplicate using gas chromatography.

Analysis indicated that both samples were principally oxygen (95-98 vol \%) with small amounts of nitrogen $(5-8 \mathrm{vol} \%)$. The small amount of nitrogen likely results from residual air that had not been displaced by the evolved oxygen. No hydrogen $(<0.1 \mathrm{vol} \%)$ was detected in either sample. The high concentration of oxygen and absence of hydrogen is consistent with the decomposition of hydrogen peroxide to produce oxygen and water.

In addition to gas evolution during the synthesis of mMST, continued gas release was observed during storage of the mMST samples as aqueous suspensions. The amount of gas released decreased with time, but was observed to continue for many months. Thus, storage of mMST would likely require vented containers to prevent overpressurization during transport and storage of the material as an aqueous suspension. Possible sources of the gas release include trapped oxygen from the synthesis of the mMST, decomposition of residual hydrogen peroxide, and decomposition of the titanium-peroxide species.

The gas release rate $\left(\mathrm{mL} \mathrm{min}^{-1}\right)$ of a freshly prepared batch of mMST (LS-5) stored as $15 \mathrm{wt} \%$ suspension at a $\mathrm{pH}$ of 4.0 was measured over time (see Figure $\mathrm{S} 1$ in 
Supporting Information). The preparation of this batch of mMST featured washing of the mMST solids with $\mathrm{pH} 7.0$ ultrapure water followed by briefly air drying on the filter. The solids were then suspended in water and the $\mathrm{pH}$ of the suspension adjusted to $\mathrm{pH} 4.0$ with dilute nitric acid.

Initially the release rate measured approximately $0.15 \mathrm{~mL} \mathrm{~min}^{-1}$ (per $125 \mathrm{~g}$ of 15 wt $\%$ slurry) and rapidly decreased by an order of magnitude within 2 days and two orders of magnitude after about 20 days. Four weeks after the preparation of the mMST, the gas release rate was $1.1 \mathrm{E}-03 \mathrm{~mL} \mathrm{~min}^{-1}$. Thus, after four weeks the gas release rate per gram of mMST slurry measured $8.8 \mathrm{E}-06 \mathrm{~mL} \mathrm{~min}^{-1} \mathrm{~g}^{-1}$. Using a value of $1.10 \mathrm{~g} \mathrm{~mL}^{-1}$ for the density of the $15 \mathrm{wt} \%$ slurry of mMST, the release rate on a slurry volume basis is approximately $14 \mathrm{~mL}$ day $^{-1} \mathrm{~L}^{-1}$.

Two additional syntheses of mMST were performed with different washing conditions to determine if the washing conditions affected post-synthesis gas release. The standard preparation of the mMST isolates the solids by filtration followed by a $\mathrm{pH}$ 7.0 water wash (LS-5). After washing and final filtration, the solids are suspended in water to a solids concentration of $15 \mathrm{wt} \%$ and the $\mathrm{pH}$ of the suspension adjusted to 4.0 with nitric acid. This washing step of the procedure was modified to incorporate either an acidic wash (pH 4, sample LS-6) or alkaline wash (pH 10, sample LS-7). In the case of the alkaline wash, the final suspension was also adjusted to a $\mathrm{pH}$ of 10 , rather than a $\mathrm{pH}$ of 4.

It was observed that after the acidic and basic washes the mMST suspensions exhibited similar gas release to the batch of material washed with $\mathrm{pH} 7.0$ water (see Figure S1). Closer inspection of the initial gas release rates revealed that the mMST 
solids washed with the alkaline wash were initially lower than those with the neutral or acidic wash waters. In fact, the gas release rate of the alkaline washed mMST solids initially measured about an order of magnitude lower than that of the mMST solids washed with neutral or acidic wash water. During the first four hours of measurements, the rate of gas release increased to about $0.025 \mathrm{~mL} \mathrm{~min}^{-1}$ and then began to decrease similarly to that observed with the neutral and acidic washed mMST materials. After 2 days the gas release measurements are not statistically different among the different batches of mMST.

Hydrogen peroxide is well known to be less stable in alkaline solutions compared to neutral or acidic solutions. ${ }^{[12]}$ Thus, the observed behavior suggests that the alkaline wash may have reduced the residual hydrogen peroxide that decomposes to release oxygen. Regardless of the $\mathrm{pH}$ of the wash water, the quantity of post-synthesis gas released from the mMST material is sufficient to require vented containers for the shipment and storage of large quantities of material.

Figure 1 provides a plot of the measured gas release rate $\left(\mathrm{mL} \mathrm{min}^{-1}\right)$ versus elapsed time (days) for a freshly prepared batch of mMST at a temperature of $49^{\circ} \mathrm{C}$ (LS-8) compared to the results from a room temperature experiment performed using the same round bottom flask apparatus (LS-9). The gas release rate at elevated temperature is consistently higher than the measured rates at room temperature. Initially the release rate at $49{ }^{\circ} \mathrm{C}$ measured approximately $0.525 \mathrm{~mL} \mathrm{~min}^{-1}$ and decreased by an order of magnitude in less than one day. After one month the release rate still measured approximately 2.7 times the rate at room temperature.

\section{Solids Settling Characteristics}


MST and mMST are fine particulate solids having particle sizes in the range of about $1-20$ microns. Settling characteristics of the MST and mMST particles are important in assessing nuclear criticality safety upon settling in batch contact reactors within operating and planned pretreatment facilities at the Savannah River Site. ${ }^{[4,5]}$ Resuspension of densely-packed solids can be an engineering concern in large batch reactors. Thus, we performed a limited number of settling tests to compare the settling characteristics of mMST and MST materials.

Figure 2 provides plots of the height of the settled solids $(\mathrm{mm})$ versus settling time (hours) for the extreme $\mathrm{pH}$ conditions tested with each sorbent material. Initially, the height of each of the suspensions measured $17.5 \mathrm{~mm}$. After 2 hours of settling, the height of the settled MST solids measured about $50 \%$ of the initial suspension height compared to about $58 \%$ for the mMST solids. The slower settling of the mMST suspensions is consistent with particle size measurements that showed a larger fraction of fines in mMST compared to MST. ${ }^{[8]}$

After 2 hours, the rate of settling decreases appreciably for both materials due to hindered settling. After 20 hours, both MST suspensions settled to about $40 \%$ of the initial height. The mMST suspensions exhibited slower settling rates in the hindered settling region reaching settled solids heights of $54 \%$ and $48 \%$ for the $\mathrm{pH} 4.84$ and $\mathrm{pH} 10$ suspensions, respectively. The overall reduced extent of settling for the mMST solids in this region is attributed to higher surface area and intraparticle porosity of the mMST solids compared to MST. ${ }^{[6]}$ The higher porosity makes it more difficult to remove water restricting further settling of the solids. 
Table 4 contains the results of the settled density measurements for mMST in both $0.5 \mathrm{M}$ and 5.6 $\mathrm{M}$ Na solutions, and at centrifuge speeds of $6.3 \mathrm{xg}$ and $1400 \mathrm{x} \mathrm{g}$. As expected, the density of the settled solids increases with increased centrifuge speed. The density also increases slightly with increasing suspended solids concentrations, with the exception of $0.15 \mathrm{~g} / \mathrm{L}$ at $6.3 \mathrm{xg}$. The effect of sodium concentration is minor, and in general does not produce a measurable difference in the density, for the sodium concentrations tested here.

Results from the gravity settling tests for MST and mMST in salt solutions with varying sodium concentrations $(4.6,5.6$, and 6.6 M) are shown in Figure 3. The rates were determined by measuring the height of the clear supernate at the top of the graduated cylinder over time. As can be seen from the graph, the mMST settling rate is much slower than the MST settling rate, indicating the mMST contains a larger fraction of smaller diameter particles. ${ }^{[8]}$ For MST, there did not appear to be a measurable effect of the sodium concentration on the settling rate. For mMST the settling rate was slightly lower in the highest sodium concentration solution. This is the expected trend, as the viscosity of the solution increases with increasing ionic strength.

\section{High Temperature X-Ray Diffraction Analyses (HTXRD)}

Previously, we reported that the mMST exhibited good thermal stability based on thermal gravimetric and differential scanning calorimetry measurements. ${ }^{[6]}$ After use, MST and mMST will be incorporated into a borosilicate glass wasteform for disposal. To provide an indication of solid phase transformations that may occur during the early 
stages of heating in a glass melter, we obtained X-ray powder diffraction data upon heating MST and mMST at temperatures ranging from 25 to $800{ }^{\circ} \mathrm{C}$.

A summary of the phases identified in these high temperature XRD experiments can be found in Table 5. Both MST and mMST samples are amorphous materials, but several crystalline phases were observed as the materials were heated from 25 to $800{ }^{\circ} \mathrm{C}$. For MST, poorly crystalline sodium titanium oxide hydrate $\left(\mathrm{Na}_{2} \mathrm{Ti}_{2} \mathrm{O}_{4}(\mathrm{OH})_{2}\right)$ was the only phase detected in both the as-received and $\mathrm{pH}$-adjusted samples from 25 to $300{ }^{\circ} \mathrm{C}$. As the powders were heated, the unit cell for this titanate phase contracted along the aaxis in the direction of the (200) plane. The contraction continued until the phase disappeared above $300{ }^{\circ} \mathrm{C}$. In the $600{ }^{\circ} \mathrm{C}$ scan, differences between the as-received and pH-adjusted samples began to emerge. Metastable phases, $\mathrm{Na}_{0.8} \mathrm{Ti}_{4} \mathrm{O}_{8}$, (only found at 600 ${ }^{\circ} \mathrm{C}$ ) and $\mathrm{Na}_{2} \mathrm{Ti}_{6} \mathrm{O}_{13}$ or $\mathrm{Na}_{2} \mathrm{O} 6 \mathrm{TiO}_{2}$ (stable to $800{ }^{\circ} \mathrm{C}$ ) appear in both samples. However, in the $\mathrm{pH}$-adjusted sample the two titanium dioxide polymorphs, anatase and rutile, were also identified at $600{ }^{\circ} \mathrm{C}$. The anatase completely transformed to rutile somewhere between $600-800^{\circ} \mathrm{C}$. At $800{ }^{\circ} \mathrm{C}$, an additional sodium titanate, $\mathrm{Na}_{2} \mathrm{Ti}_{3} \mathrm{O}_{7}$ or $\mathrm{Na}_{2} \mathrm{O} 3 \mathrm{TiO}_{2}$, appears in the as-received sample. The room temperature XRD analysis of the HTXRD residues found the same phases that were present at $800^{\circ} \mathrm{C}$ in the high temperature scans.

The HTXRD results for the mMST decomposition were similar to those for the baseline MST with a few notable differences. Although sodium titanium oxide hydrate $\left(\mathrm{Na}_{2} \mathrm{Ti}_{2} \mathrm{O}_{4}(\mathrm{OH})_{2}\right)$ or a similar compound, such as sodium peroxotitanate, may also be present in both samples from $25^{\circ} \mathrm{C}$ to $300^{\circ} \mathrm{C}$, the main phase identified was nanocrystalline anatase. Both the as-received and $\mathrm{pH}$-adjusted samples exhibit the same unit 
cell contraction along the a-axis in the direction of the (200) plane as mentioned above. The main difference in the decomposition for the mMST samples occurs at $600{ }^{\circ} \mathrm{C}$, with the metastable phase, $\mathrm{Na}_{0.8} \mathrm{Ti}_{4} \mathrm{O}_{8}$, only observed in the $\mathrm{pH}$-adjusted sample. As in the monosodium titanate $\mathrm{HTXRD}$ runs, at $800^{\circ} \mathrm{C}$ and in the HTXRD residues, rutile and $\mathrm{Na}_{2} \mathrm{Ti}_{6} \mathrm{O}_{13}$ were identified.

\section{Iodometric Titration Analysis}

Several batches of mMST of different ages, both lab prepared and vendor prepared, were analyzed using the iodometric titration method. The amount of peroxide in the samples was found to decrease linearly with the age of the sample (Figure 4). There was one exception to this trend, sample LS-8. This lab prepared sample had been held at 49 ${ }^{\circ} \mathrm{C}$ for one month (for gas release measurements), whereas the other samples had not been exposed to elevated temperatures. Sample LS-8 contained approximately one-half the amount of peroxide of a slightly older sample, LS-7.

Results from the titration of mMST samples synthesized using different $\mathrm{H}_{2} \mathrm{O}_{2}$ :Ti ratios showed a logarithmic trend between the amount of peroxide added during the synthesis and the amount of peroxide present in the product.

\section{Affect of Alkaline Solution on Peroxide Content}

Results from the effect of salt solution experiments showed a significant decrease in peroxide content after exposure to the two salt solutions. The experiment using only distilled water showed a peroxide content within error of the previous results for this sample (Optima Batch 06-QAB-0139). This control experiment was designed to account for any loss of material during the soaking and recovery process, since the initial weight 
added to the salt solutions was used to determine the peroxide:Ti ratio. The peroxide:Ti ratios for these samples are presented in Table 6 . The salt solution containing only sodium (SWS-1-2010) resulted in the largest reduction of peroxide content, to only about $42 \%$ of the control value. The Sr-containing salt solution (SWS-1-2008) resulted in a slightly higher peroxide content, $58 \%$ of the control value.

\section{Affect of Age on mMST Performance}

Figures 5-6 show the Pu and Np decontamination factors (DFs) obtained for each of the samples listed in Table 3. As can be seen from Figure 5, the Pu DFs for the oldest sample (LS-2) were significantly lower than the Pu DFs obtained with the other samples. Sample LS-8, which iodometric titration indicated had a reduced amount of peroxide, also showed lower Pu DFs. The Pu DFs for samples LS-7 and LS-9 were not statistically different at the 6 and 24 hour sampling times. Plutonium content in the samples from the 12 hour sampling time fell below the method detection limit, resulting in greater than values calculated for the DFs. Figure 6 shows the DF values for ${ }^{237} \mathrm{~Np}$. In this case LS-8 shows the highest ${ }^{237} \mathrm{~Np}$ DFs, whereas the DFs for the other samples are not statistically different from each other. It is difficult to draw any conclusions regarding the ${ }^{85} \mathrm{Sr}$

removal, since ${ }^{85} \mathrm{Sr}$ concentrations in many of the samples fell below the method detection limit, resulting in greater than values being obtained for the DFs. However, it does appear that LS-2, the oldest sample, resulted in the least Sr removal, as the results for all time points for this sample were above the method detection limit. At the 6 hour time point, the Sr DF for LS-2 is clearly lower than that obtained for LS-8 and LS-9; however, at the later time points this conclusion cannot be drawn as the value falls within error of the minimum DF values for LS-8 and LS-9. There appears to be no effect of age 
on the uranium sorption of these materials. None of the samples appear to adsorb a measurable amount of uranium.

The performance of sample LS-2 has been measured a total of six times over a time period of approximately 56 months, including the results shown above. ${ }^{[9]}$ Testing up to an age of 30 months showed no measurable decrease in Pu DF. However, the final testing at an age of 56.4 months showed a significant decrease in Pu DF to a value only $18 \%$ of the Pu DF averaged over the earlier test dates (Figure 7).

Testing was also performed using a U only simulant with high sorbent loadings $(3.0 \mathrm{~g} / \mathrm{L})$ to determine if mMST begins to absorb uranium as the peroxide is lost with age. Similar testing with uranium only simulant was performed with these same batches of MST (Optima 00-QAB-417) and mMST (Optima 06-QAB-0139) 26 months earlier. These earlier results were used for comparison to determine if the loss of peroxide over time caused an increase in uranium uptake by the mMST. For the MST there is no measurable change in the uranium sorption between the two sets of data. For the mMST, there is an increase in the uranium sorption measured at the 12-hour time point (see Figure 8). The decontamination factor measured in 2009 was $1.21 \pm 0.0109$ compared to $1.10 \pm 0.0178$ in 2007.

\section{CONCLUSIONS}

The mMST material has been characterized to determine the gas release characteristics, thermal stability, settling characteristics, and peroxide content. Several characterizations also focused on how the material changes with age in order to establish a shelf-life of the material. The mMST material was found to release oxygen rapidly 
during the synthesis and continue to release gas at diminishing rates for an extended period of time. The short-term ( $<2$ days) gas release rate was diminished by washing the mMST solids with alkaline water ( $\mathrm{pH} 10)$. After several days the rate of post-synthesis gas release appeared similar regardless of the washing conditions. The quantity of postsynthesis gas released from the mMST material is sufficient to require vented containers for the shipment and storage of large quantities of material.

In the settling tests, mMST was found to settle at a slower rate than MST. The extent of mMST solids settling was also dependent on $\mathrm{pH}$, unlike MST. Increased settling of mMST occurred with an increase in $\mathrm{pH}$ of the suspension. The ionic strength of solution did not appear to have a large effect on the settling rates of MST or mMST. For mMST there was a slight decrease in the settling rate in the highest sodium concentration tested, while there was no measurable change in settling rate for MST.

Although MST and mMST are amorphous materials, several crystalline phases were identified in the HTXRD analyses as these samples were heated from 25 to $800{ }^{\circ} \mathrm{C}$. A major difference between the baseline and modified MST samples was that the major phase for mMST from 25 to $300{ }^{\circ} \mathrm{C}$ was nano-crystalline anatase, where as poorly crystalline sodium titanium oxide hydrate $\left(\mathrm{Na}_{2} \mathrm{Ti}_{2} \mathrm{O}_{4}(\mathrm{OH})_{2}\right)$ was the only phase detected in the same temperature range for baseline MST. Differences in the $\mathrm{pH}$ adjusted and asreceived samples are only observed at temperatures of $600{ }^{\circ} \mathrm{C}$ and above for both the baseline and modified MST samples.

Iodometric titration was used to determine the peroxide content of the mMST samples. Results from these tests indicated a loss of peroxide content with age or extended exposure to elevated temperatures. A logarithmic trend between peroxide 
added during the synthesis and peroxide present in the resulting materials was also determined using this method. Further testing indicated a loss of peroxide content after exposure of the material to an alkaline salt solution, similar in composition to the simulated waste solutions used for performance testing. Performance testing also indicated some loss of actinide removal efficiency with age, especially for samples over four years of age.

\section{ACKNOWLEDGEMENTS}

We thank the U.S. Department of Energy for funding this work through the Office of Waste Processing in the Office of Environmental Management. The authors thank the technical staff at the Savannah River National Laboratory for their assistance in completing the experimental work including Mona Blume and Kimberly Wyszynksi, as well as the contributions of David Diprete, Ceci Diprete, and Curtis Johnson, in completing the many radiochemical and elemental analyses. 


\section{REFERENCES}

1. Lynch, R.; Dosch, R.; Kenna, B.; Johnstone, J.; Nowak, E. (1976) The Sandia Solidification Process - a Broad Range Aqueous Solidification Method. IAEA Symposium on the Management of Radioactive Waste, Vienna, Austria: 360-372.

2. Lynch, R. W. (1976) Sandia Solidification Process Cumulative Report. Technical Report SAND-76-0105, Sandia Laboratories, Albuquerque, NM, January 1976.

3. Dosch, R. G. (1978) The Use of Titanates in Decontamination of Defense Wastes. Technical Report SAND-78-0710, Sandia Laboratories, Albuquerque, NM, June 1978.

4. Hobbs, D. T.; Barnes, M. J.; Pulmano, R. L.; Marshall, K. M.; Edwards, T. B.; Bronikowski, M. G.; Fink, S. D. (2005) Strontium and Actinide Separations from High Level Nuclear Waste Solutions Using Monosodium Titanate 1. Simulant Testing. Separation Science and Technology, 40 (15): 3093.

5. Peters, T. B.; Barnes, M. J.; Hobbs, D. T.; Walker, D. D.; Fondeur, F. F.; Norato, M. A.; Fink, S. D.; Pulmano, R. L. (2006) Strontium and Actinide Separations from High Level Nuclear Waste Solutions Using Monosodium Titanate 2. Actual Waste Testing. Separation Science and Technology, 41 (11): 2409.

6. Nyman, M.; Hobbs, D. T. (2006) A Family of Peroxo-titanate Materials Tailored for Optimal Strontium and Actinide Sorption. Chem. Mater. 18 (26): 6425.

7. Hobbs, D. T.; Nyman, M. D.; Tripathi, A.; Medvedev, D.; Clearfield, A. (2005) Development of Improved Sorbents for Radiochemical Separations at the Savannah River Site. Proceedings of the Symposium on Waste Management, Tucson, AZ, February 27 - March 3, 2005. 
8. Hobbs, D. T.; Nyman, M. D.; Poirier, M. R.; Barnes, M. J.; Stallings, M. E. (2006) Development of an Improved Sodium Titanate for the Pretreatment of Nuclear Waste at the Savannah River Site. Proceedings of the Symposium on Waste Management, Tucson, AZ, February 26 - March 2, 2006.

9. Hobbs, D. T.; Poirier, M. R.; Barnes, M. J.; Peters, T. B.; Fondeur, F. F.; Thompson, M. E.; Fink, S. D. (2008) Development of an Improved Sodium Titanate for the Pretreatment of Nuclear Waste at the Savannah River Site. Proceedings of the Symposium on Waste Management, Tucson, AZ, February 24 $-28,2008$.

10. Dinnebier, R. E. "Material Phase Transitions/Melting Point Temperature", http://www.mpi- stuttgart.mpg.de/xray/html/temperature_calibration.html.

11. "Calibration Standards", http://www.chemistry.ohio-state.edu/ gallaghe/ta/calib_ stand.htm.

12. Cotton, F. A.; Wilkinson, G. (1972) Advanced Inorganic Chemistry - A Comprehensive Text, $3^{\text {rd }}$ Edition, pp 414 - 416; Interscience Publishers: New York. 
TABLES

Table 1. Composition of Salt Solutions.

\begin{tabular}{|c|c|c|c|}
\hline Component & Units & SWS-1-2010 & SWS-1-2008 \\
\hline $\mathrm{NaNO}_{3}$ & M & 2.60 & 2.60 \\
\hline $\mathrm{NaOH}$ & $M$ & 1.33 & 1.33 \\
\hline $\mathrm{Na}_{2} \mathrm{SO}_{4}$ & $M$ & 0.581 & 0.521 \\
\hline $\mathrm{NaAl}_{4}(\mathrm{OH})_{4}$ & $M$ & 0 & 0.429 \\
\hline $\mathrm{NaNO}_{2}$ & $M$ & 0.149 & 0.134 \\
\hline $\mathrm{Na}_{2} \mathrm{CO}_{3}$ & $M$ & 0.029 & 0.026 \\
\hline Total $\mathrm{Na}$ & $M$ & 5.6 & 5.6 \\
\hline Total Sr & $\mathrm{mg} \mathrm{L}^{-1}$ & 0 & 5.5 \\
\hline
\end{tabular}

Table 2. Age of mMST Samples.

\begin{tabular}{|c|c|}
\hline Sample & $\begin{array}{c}\text { Age at Time of Testing } \\
\text { in years }\end{array}$ \\
\hline LS-2 & 4.70 \\
\hline LS-7 & 0.30 \\
\hline LS-8 & 0.19 \\
\hline LS-9 & 0.09 \\
\hline
\end{tabular}

*Sample LS-8 was used in the gas release experiment at elevated temperature, therefore this sample was held at $49^{\circ} \mathrm{C}$ for one month. Iodometric titration analysis indicates the peroxide content for this sample is lower than predicted based on age.

Table 3. Composition of Simulated Waste Solutions

\begin{tabular}{|c|c|c|c|c|}
\hline \multirow{2}{*}{ Component } & \multicolumn{2}{|c|}{ SWS-9-2009 } & \multicolumn{2}{|c|}{ SWS-8-2007 } \\
\hline & Target & Measured & Target & Measured \\
\hline $\mathrm{NaNO}_{3}$ & $2.60 \mathrm{M}$ & $2.35 \pm 0.18 \mathrm{M}$ & $2.60 \mathrm{M}$ & $3.11 \pm 0.31 \mathrm{M}$ \\
\hline $\mathrm{NaOH}$ & $1.33 \mathrm{M}$ & $1.27 \pm 0.13 \mathrm{M}$ & $1.33 \mathrm{M}$ & $1.38 \pm 0.138 \mathrm{M}$ \\
\hline $\mathrm{Na}_{2} \mathrm{SO}_{4}$ & $0.521 \mathrm{M}$ & $0.531 \pm 0.040 \mathrm{M}$ & $0.521 \mathrm{M}$ & $0.606 \pm 0.0909 \mathrm{M}$ \\
\hline $\mathrm{NaAl}(\mathrm{OH})_{4}$ & $0.429 \mathrm{M}$ & $0.389 \pm 0.039 \mathrm{M}$ & $0.429 \mathrm{M}$ & $0.461 \pm 0.0461 \mathrm{M}$ \\
\hline $\mathrm{NaNO}_{2}$ & $0.134 \mathrm{M}$ & $0.127 \pm 0.010 \mathrm{M}$ & $0.134 \mathrm{M}$ & $0.160 \pm 0.032 \mathrm{M}$ \\
\hline $\mathrm{Na}_{2} \mathrm{CO}_{3}$ & $0.0260 \mathrm{M}$ & $0.0302 \pm 0.0030$ & $0.026 \mathrm{M}$ & $\begin{array}{c}0.0314 \pm 0.00471 \\
M\end{array}$ \\
\hline Total Na $^{+}$ & $5.6 \mathrm{M}$ & $5.05 \pm 0.01 \mathrm{M}$ & $5.60 \mathrm{M}$ & $5.10 \pm 0.51 \mathrm{M}$ \\
\hline Total Sr & $0.6 \mathrm{mg} / \mathrm{L}$ & $0.676 \pm 0.026 \mathrm{mg} / \mathrm{L}$ & 0 & - \\
\hline${ }^{85} \mathrm{Sr}$ & $\geq 10,000 \mathrm{dpm} / \mathrm{mL}$ & $12,000 \mathrm{dmp} / \mathrm{mL}$ & 0 & - \\
\hline Total Pu & $0.2 \mathrm{mg} / \mathrm{L}$ & $0.17 \pm 0.033 \mathrm{mg} / \mathrm{L}$ & 0 & - \\
\hline${ }^{237} \mathbf{N p}$ & $0.5 \mathrm{mg} / \mathrm{L}$ & $0.463 \pm 0.026 \mathrm{mg} / \mathrm{L}$ & 0 & - \\
\hline Total U & $10 \mathrm{mg} / \mathrm{L}$ & $10.1 \pm 0.36 \mathrm{mg} / \mathrm{L}$ & $10 \mathrm{mg} / \mathrm{L}$ & $9.55 \pm 0.29 \mathrm{mg} / \mathrm{L}$ \\
\hline${ }^{137} \mathrm{Cs}$ & $\geq 30,000 \mathrm{dpm} / \mathrm{mL}$ & $123,000 \pm 6130 \mathrm{dpm} / \mathrm{mL}$ & 0 & - \\
\hline
\end{tabular}


Table 4. Results of Settled Density Measurements for mMST.

\begin{tabular}{|c|c|c|c|c|}
\hline & \multicolumn{2}{|c|}{$\begin{array}{c}\text { Sodium Concentration of Settling } \\
\text { Fluid is } 5.6 \mathrm{M}\end{array}$} & \multicolumn{2}{|c|}{$\begin{array}{c}\text { Sodium Concentration of Settling } \\
\text { Fluid is } 0.5 \mathrm{M}\end{array}$} \\
\hline $\begin{array}{c}\text { Suspended } \\
\text { Solids Conc. } \\
(\mathrm{g} / \mathrm{mL}) \\
\end{array}$ & $\begin{array}{c}\text { Ave. Settled } \\
\text { Solids Conc. } \\
\text { (g/mL) at } 6.3 \times \text { g }\end{array}$ & $\begin{array}{l}\text { St. Dev. of Settled } \\
\text { Solids Conc. } \\
(\mathrm{g} / \mathrm{mL}) \text { at } 6.3 \times \mathrm{g}\end{array}$ & $\begin{array}{c}\text { Ave. Settled } \\
\text { Solids Conc. } \\
\text { (g/mL) at } 6.3 \times \text { g }\end{array}$ & $\begin{array}{l}\text { St. Dev. of Settled } \\
\text { Solids Conc. } \\
\text { (g/mL) at } 6.3 \times \mathrm{g}\end{array}$ \\
\hline 0.03 & 0.188 & 0.0073 & 0.212 & 0.0150 \\
\hline 0.09 & 0.201 & 0.0018 & 0.214 & 0.0051 \\
\hline 0.15 & 0.197 & 0.0000 & 0.197 & 0.0000 \\
\hline & \multicolumn{2}{|c|}{$\begin{array}{c}\text { Sodium Concentration of Settling } \\
\text { Fluid is } 5.6 \mathrm{M}\end{array}$} & \multicolumn{2}{|c|}{$\begin{array}{c}\text { Sodium Concentration of Settling } \\
\text { Fluid is } 0.5 \mathrm{M}\end{array}$} \\
\hline $\begin{array}{l}\text { Suspended } \\
\text { Solids Conc. } \\
\text { (g/mL) }\end{array}$ & $\begin{array}{c}\text { Ave. Settled } \\
\text { Solids Conc. } \\
\text { (g/mL) at } 1400 \mathrm{x} \\
\mathrm{g}\end{array}$ & $\begin{array}{l}\text { St. Dev. of Settled } \\
\text { Solids Conc. } \\
\text { (g/mL) at } 1400 \times \mathrm{g}\end{array}$ & $\begin{array}{c}\text { Ave. Settled } \\
\text { Solids Conc. } \\
(\mathrm{g} / \mathrm{mL}) \text { at } 1400 \mathrm{x} \\
\mathrm{g}\end{array}$ & $\begin{array}{l}\text { St. Dev. of Settled } \\
\text { Solids Conc. } \\
(\mathrm{g} / \mathrm{mL}) \text { at } 1400 \times \mathrm{g}\end{array}$ \\
\hline 0.03 & 0.300 & 0.0196 & 0.318 & 0.0039 \\
\hline 0.09 & 0.338 & 0.0036 & 0.342 & 0.0020 \\
\hline 0.15 & 0.365 & 0.0118 & 0.348 & 0.0052 \\
\hline
\end{tabular}


Table 5. Summary of Phases Identified in HTXRD Experiments.

\begin{tabular}{|c|c|c|}
\hline \multicolumn{3}{|c|}{ Baseline MST As Received } \\
\hline Compound & Formula & Temperature $\left({ }^{\circ} \mathbf{C}\right)$ in $\mathrm{He}$ \\
\hline Sodium Titanium Oxide Hydrate & $\mathrm{Na}_{2} \mathrm{Ti}_{2} \mathrm{O}_{4}(\mathrm{OH})_{2}$ & $25-300$ \\
\hline Sodium Titanium Oxide & $\mathrm{Na}_{0.8} \mathrm{Ti}_{4} \mathrm{O}_{8}$ & 600 \\
\hline Sodium Titanium Oxide & $\mathrm{Na}_{2} \mathrm{Ti}_{6} \mathrm{O}_{13}$ & $600-800$, residue \\
\hline Sodium Titanium Oxide & $\mathrm{Na}_{2} \mathrm{Ti}_{3} \mathrm{O}_{7}$ & 800, residue \\
\hline \multicolumn{3}{|c|}{ Baseline MST pH Adjusted } \\
\hline Compound & Formula & Temperature $\left({ }^{\circ} \mathrm{C}\right)$ in $\mathrm{He}$ \\
\hline Sodium Titanium Oxide Hydrate & $\mathrm{Na}_{2} \mathrm{Ti}_{2} \mathrm{O}_{4}(\mathrm{OH})_{2}$ & $25-300$ \\
\hline Sodium Titanium Oxide & $\mathrm{Na}_{0.8} \mathrm{Ti}_{4} \mathrm{O}_{8}$ & 600 \\
\hline Anatase & $\mathrm{TiO}_{2}$ & 600 \\
\hline Sodium Titanium Oxide & $\mathrm{Na}_{2} \mathrm{Ti}_{6} \mathrm{O}_{13}$ & $600-800$, residue \\
\hline Rutile & $\mathrm{TiO}_{2}$ & $600-800$, residue \\
\hline \multicolumn{3}{|c|}{ mMST As Received } \\
\hline Compound & Formula & Temperature $\left({ }^{\circ} \mathrm{C}\right)$ in $\mathrm{He}$ \\
\hline Sodium Titanium Oxide Hydrate & $\mathrm{Na}_{2} \mathrm{Ti}_{2} \mathrm{O}_{4}(\mathrm{OH})_{2}$ & $25-300(?)$ \\
\hline Anatase & $\mathrm{TiO} 2$ & $25-600$ \\
\hline Rutile & $\mathrm{TiO}_{2}$ & 800 , residue \\
\hline Sodium Titanium Oxide & $\mathrm{Na}_{2} \mathrm{Ti}_{6} \mathrm{O}_{13}$ & 800 , residue \\
\hline \multicolumn{3}{|c|}{ mMST pH Adjusted } \\
\hline Compound & Formula & Temperature $\left({ }^{\circ} \mathrm{C}\right)$ in $\mathrm{He}$ \\
\hline Sodium Titanium Oxide Hydrate & $\mathrm{Na}_{2} \mathrm{Ti}_{2} \mathrm{O}_{4}(\mathrm{OH})_{2}$ & $25-300(?)$ \\
\hline Anatase & $\mathrm{TiO} 2$ & $25-600$ \\
\hline Sodium Titanium Oxide & $\mathrm{Na}_{0.8} \mathrm{Ti}_{4} \mathrm{O}_{8}$ & 600 \\
\hline Rutile & $\mathrm{TiO}_{2}$ & 800 , residue \\
\hline Sodium Titanium Oxide & $\mathrm{Na}_{2} \mathrm{Ti}_{6} \mathrm{O}_{13}$ & 800 , residue \\
\hline
\end{tabular}

Table 6. Peroxide:Ti Ratios for mMST Optima Batch 06-QAB-0139.

\begin{tabular}{|c|c|c|c||}
\hline mMST Sample & Salt Solution & Peroxide/Ti ratio & \% of Control Value \\
\hline 06-QAB-0139 & None & $0.202 \pm 0.0018$ & n/a \\
\hline 06-QAB-0139 & Control - Water & $0.211 \pm 0.0086$ & 100 \\
\hline 06-QAB-0139 & SWS-1-2010 & $0.089 \pm 0.0034$ & 42.2 \\
\hline 06-QAB-0139 & SWS-1-2008 & $0.123 \pm 0.0034$ & 58.3 \\
\hline
\end{tabular}




\section{FIGURE CAPTIONS}

Figure 1. Comparison of gas release rates from $\mathrm{mMST}$ at room temperature (diamonds, solid line) and at $49^{\circ} \mathrm{C}$ (squares, dashed line).

Figure 2. Height of Settled Solids versus Settling Time for mMST (black) at a pH of 4.84 (filled circles) and a pH of 10 (open circles) and Baseline MST (gray) at a pH of 6 (open squares) and a pH of 10.47 (filled squares).

Figure 3. MST (filled symbols) and mMST (open symbols) fines settling rates vs. time in 4.6 M (circles), 5.6 M (diamonds), and 6.6 M (triangles) Na concentration salt solutions.

Figure 4. Peroxide content of mMST samples vs. age (LS-8 is excluded from the linear regression).

Figure 5. Pu DF versus contact time for LS-2, age 4.7 yr (diamonds), LS-7, age 0.3 yr (squares), LS-8, age 0.19 yr (accelerated aging) (triangles) and LS-9, age 0.09 yr (circles).

Figure 6. ${ }^{237} \mathrm{~Np}$ DF versus contact time for LS-2, age $4.7 \mathrm{yr}$ (diamonds), LS-7, age 0.3 yr (squares), LS-8, age 0.19 yr (accelerated aging) (triangles) and LS-9, age 0.09 yr (circles).

Figure 7. 6-h (diamonds) and 12-h (squares) Pu DFs for LS-2 as a function of elapsed time since preparation.

Figure 8. Uranium decontamination factors for mMST (Optima 06-QAB-0139) measured in October 2007 (gray) and in December 2009 (black). 


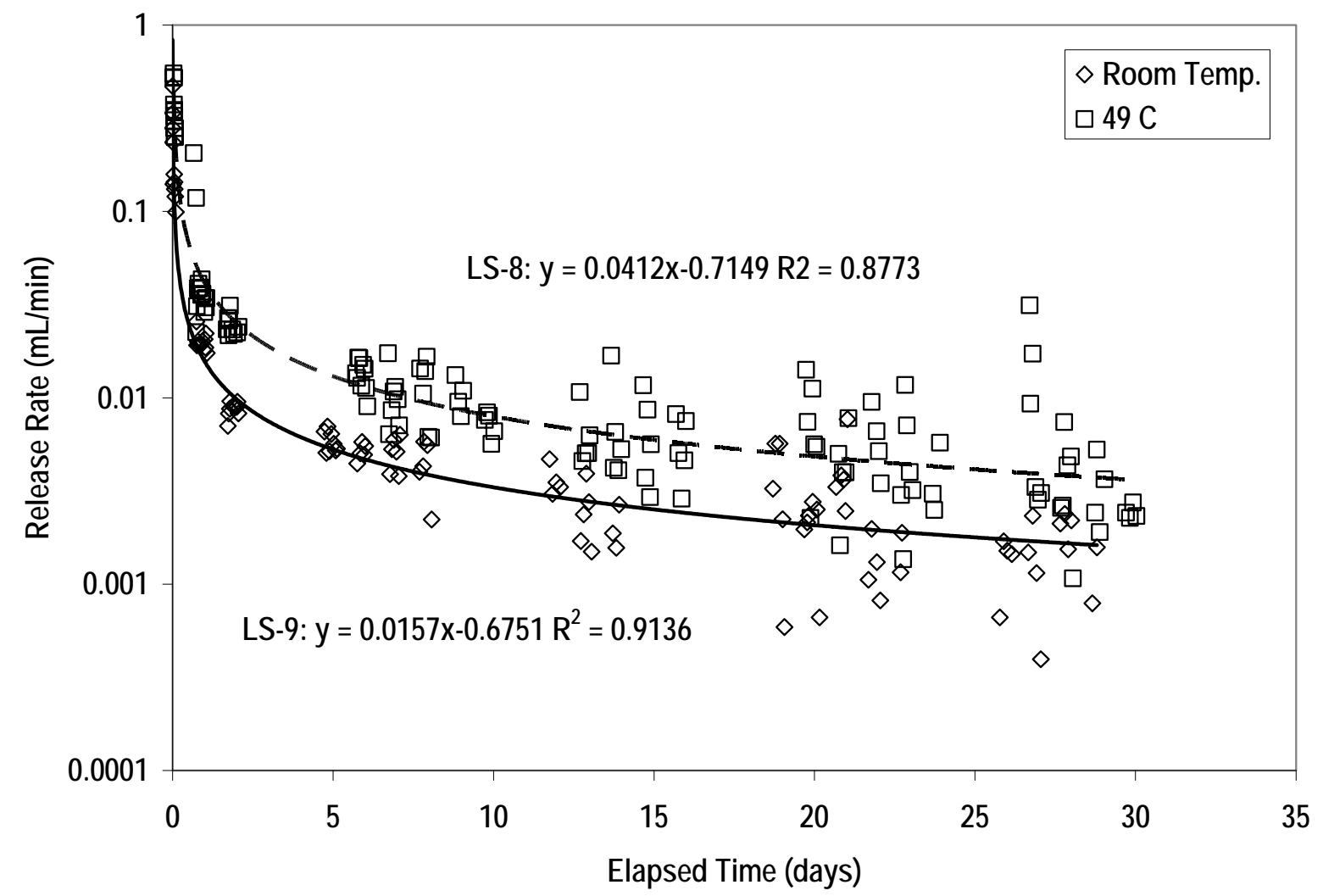

Figure 1. Comparison of gas release rates from $\mathrm{mMST}$ at room temperature (diamonds, solid line) and at $49^{\circ} \mathrm{C}$ (squares, dashed line). 


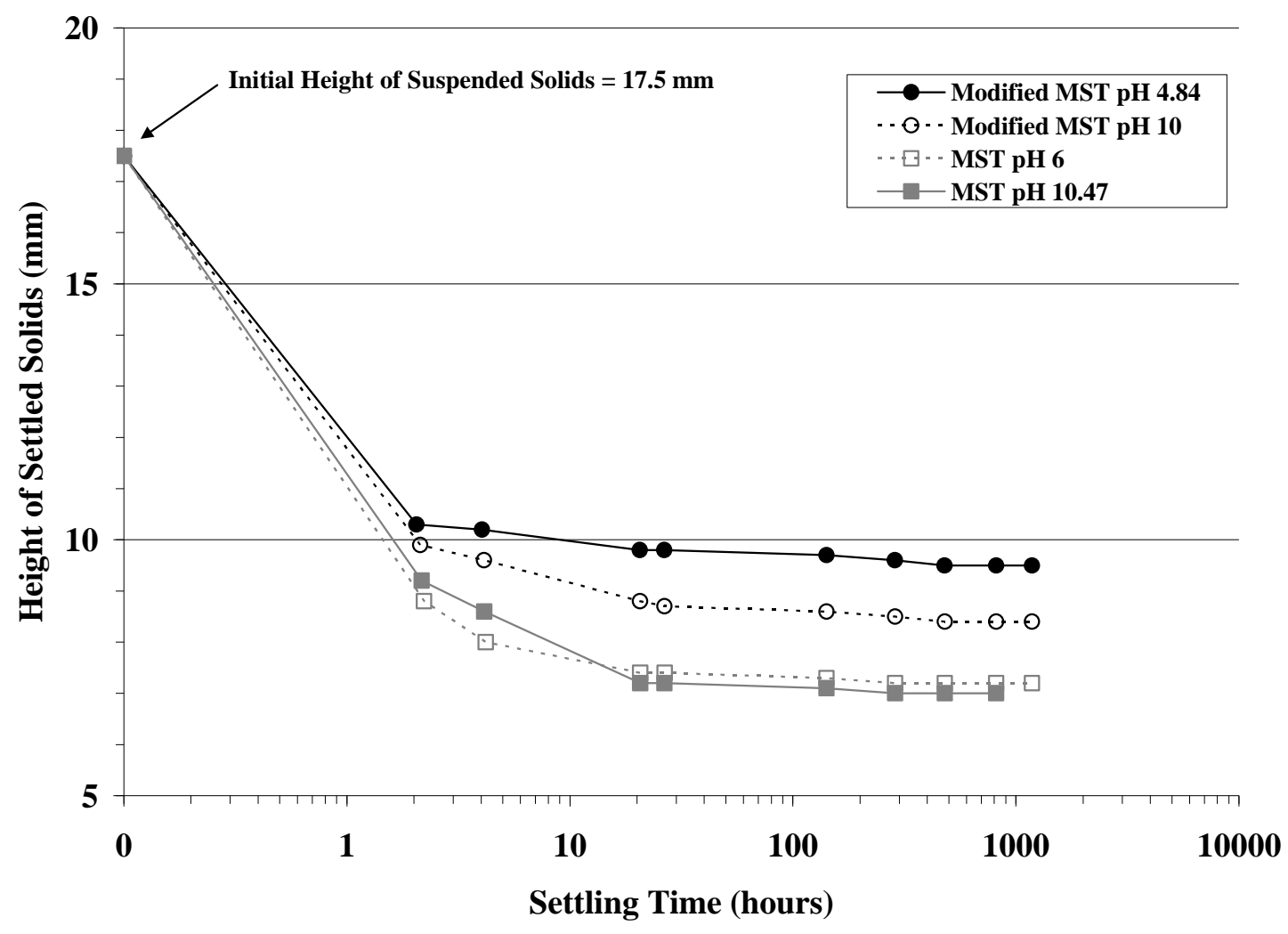

Figure 2. Height of Settled Solids versus Settling Time for mMST (black) at a pH of 4.84 (filled circles) and a pH of 10 (open circles) and Baseline MST (gray) at a pH of 6 (open squares) and a pH of 10.47 (filled squares). 


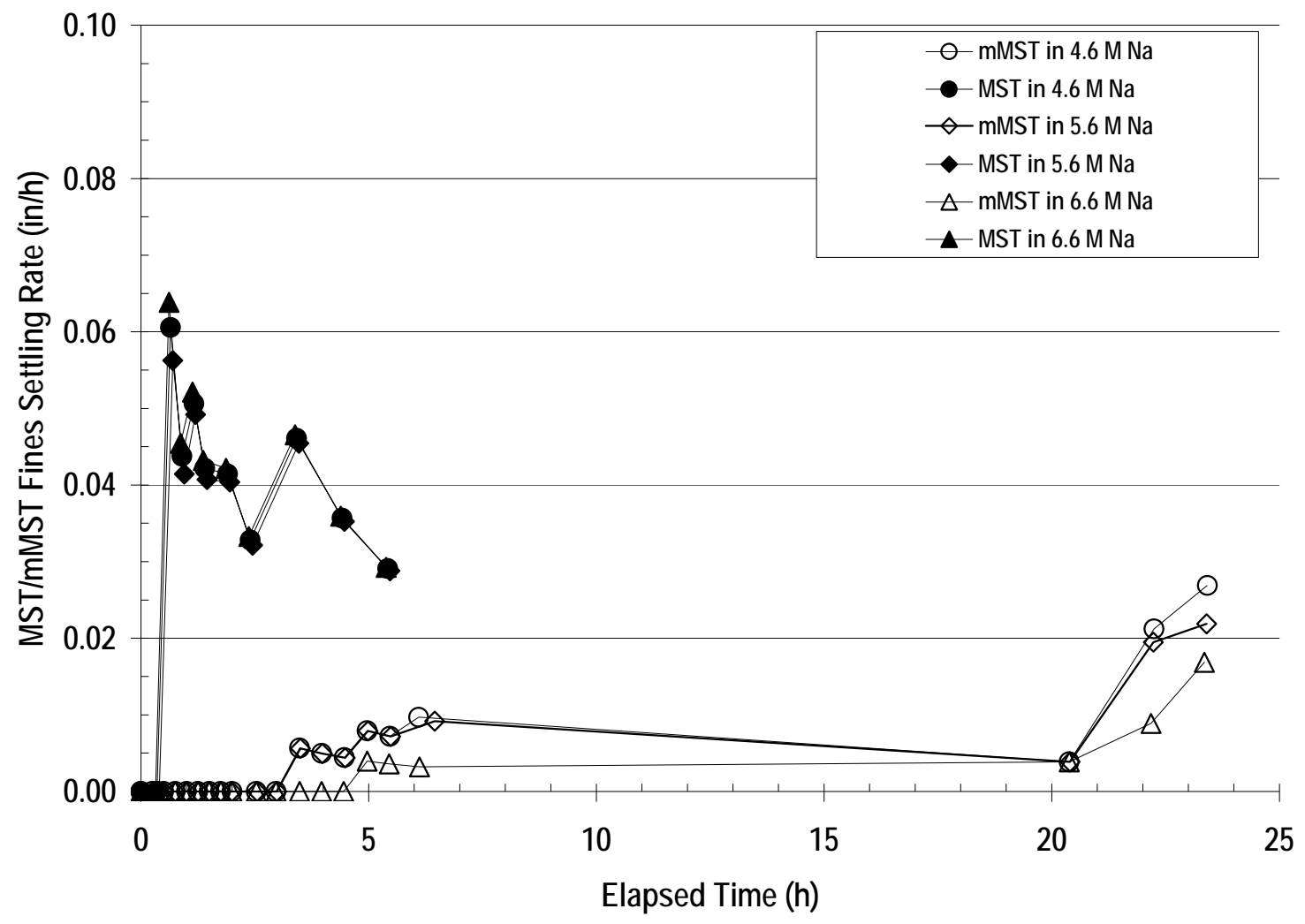

Figure 3. MST (filled symbols) and mMST (open symbols) fines settling rates vs. time in 4.6 M (circles), 5.6 M (diamonds), and 6.6 M (triangles) Na concentration salt solutions. 


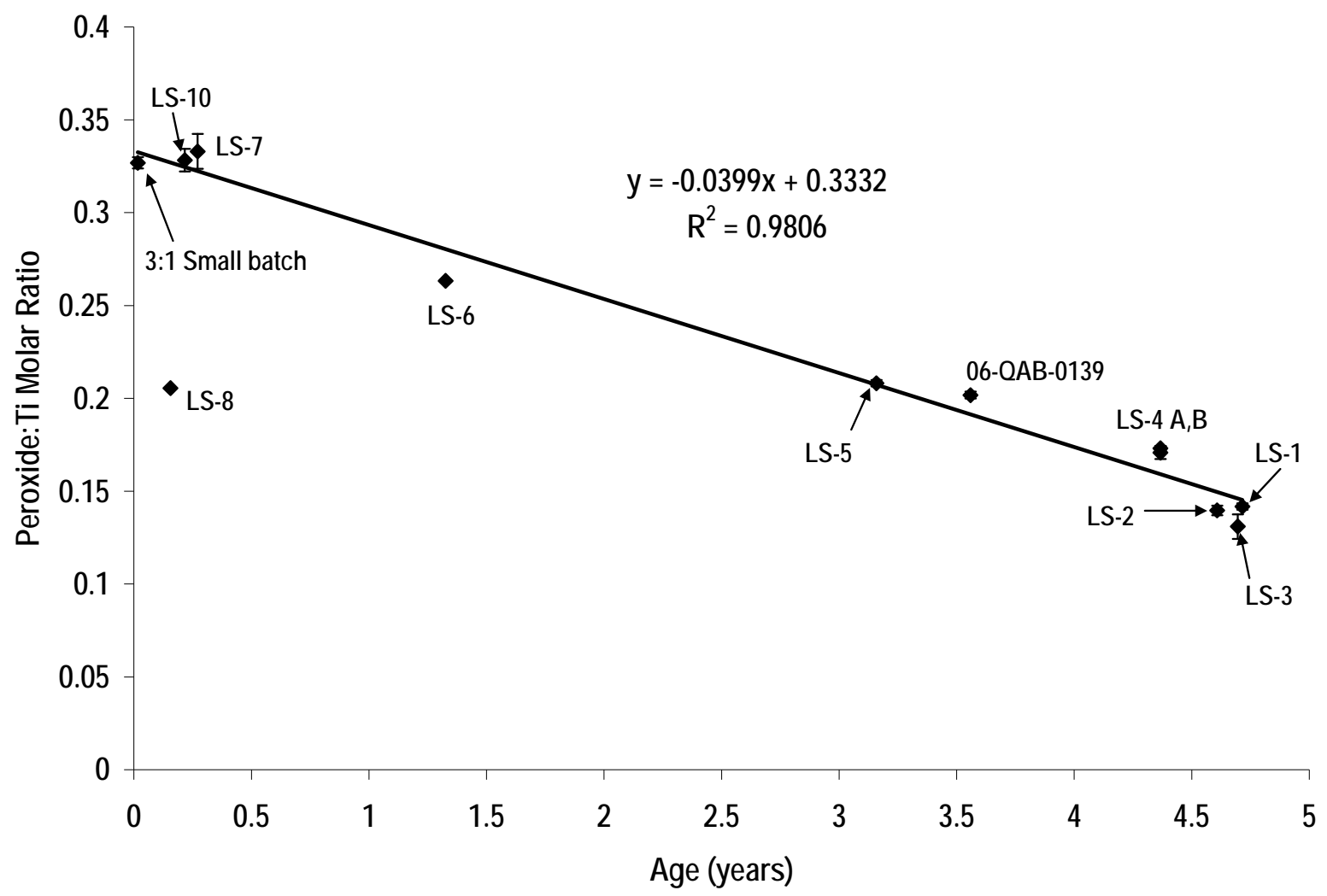

Figure 4. Peroxide content of mMST samples vs. age (LS-8 is excluded from the linear regression). 


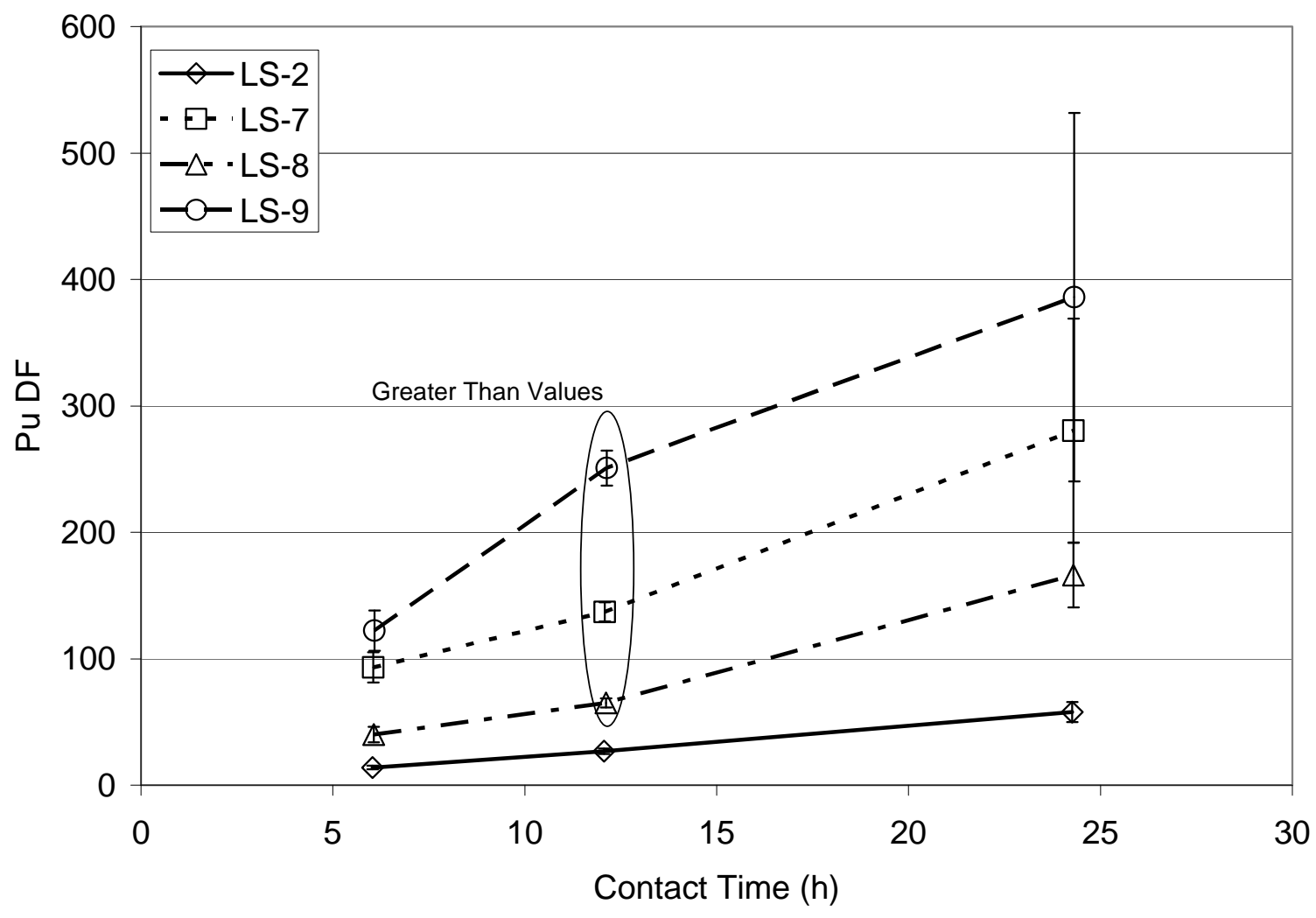

Figure 5. Pu DF versus contact time for LS-2, age 4.7 yr (diamonds), LS-7, age 0.3 yr (squares), LS-8, age 0.19 yr (accelerated aging) (triangles) and LS-9, age 0.09 yr (circles). 


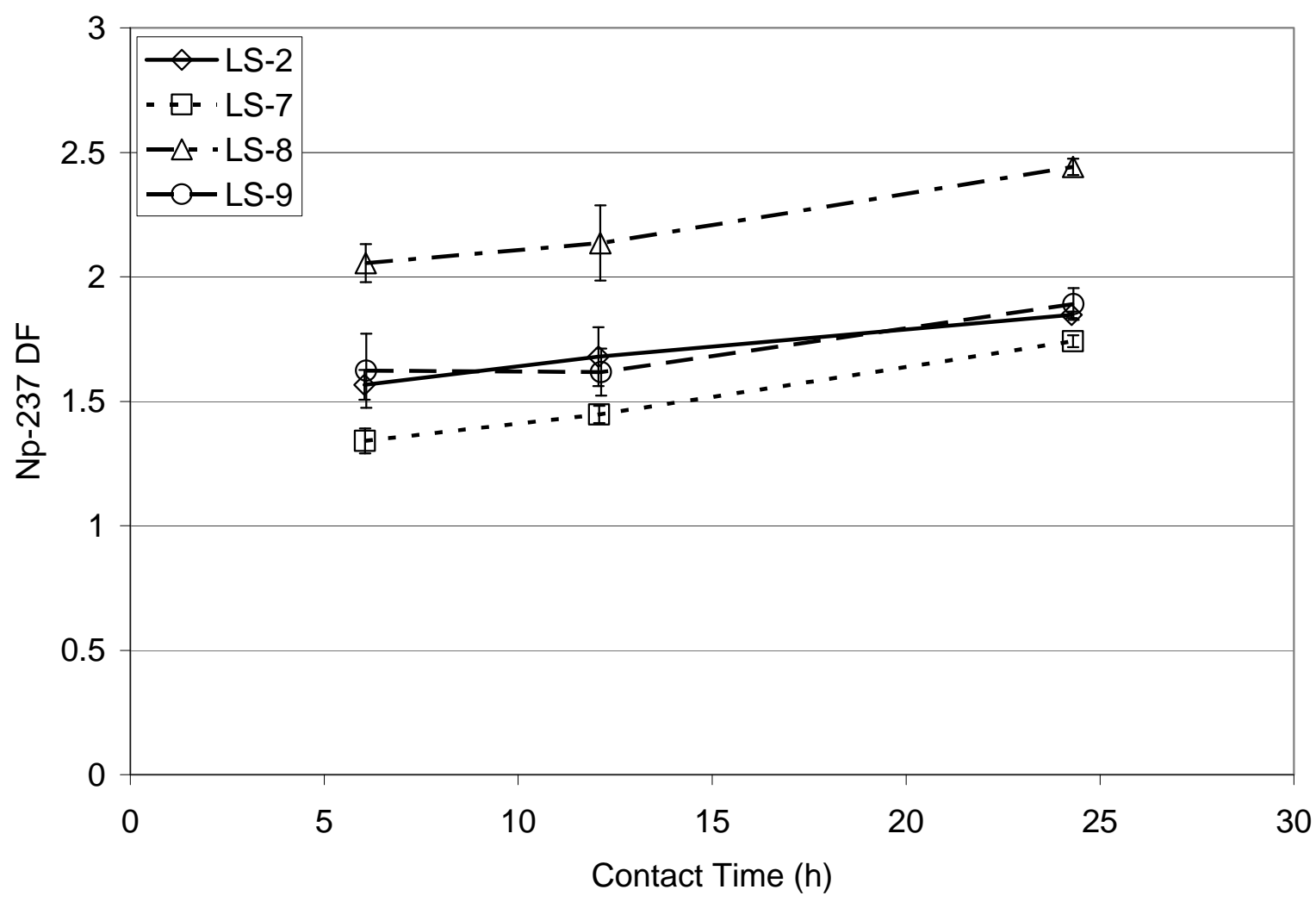

Figure 6. ${ }^{237} \mathrm{~Np}$ DF versus contact time for LS-2, age $4.7 \mathrm{yr}$ (diamonds), LS-7, age 0.3 yr (squares), LS-8, age 0.19 yr (accelerated aging) (triangles) and LS-9, age 0.09 yr (circles). 


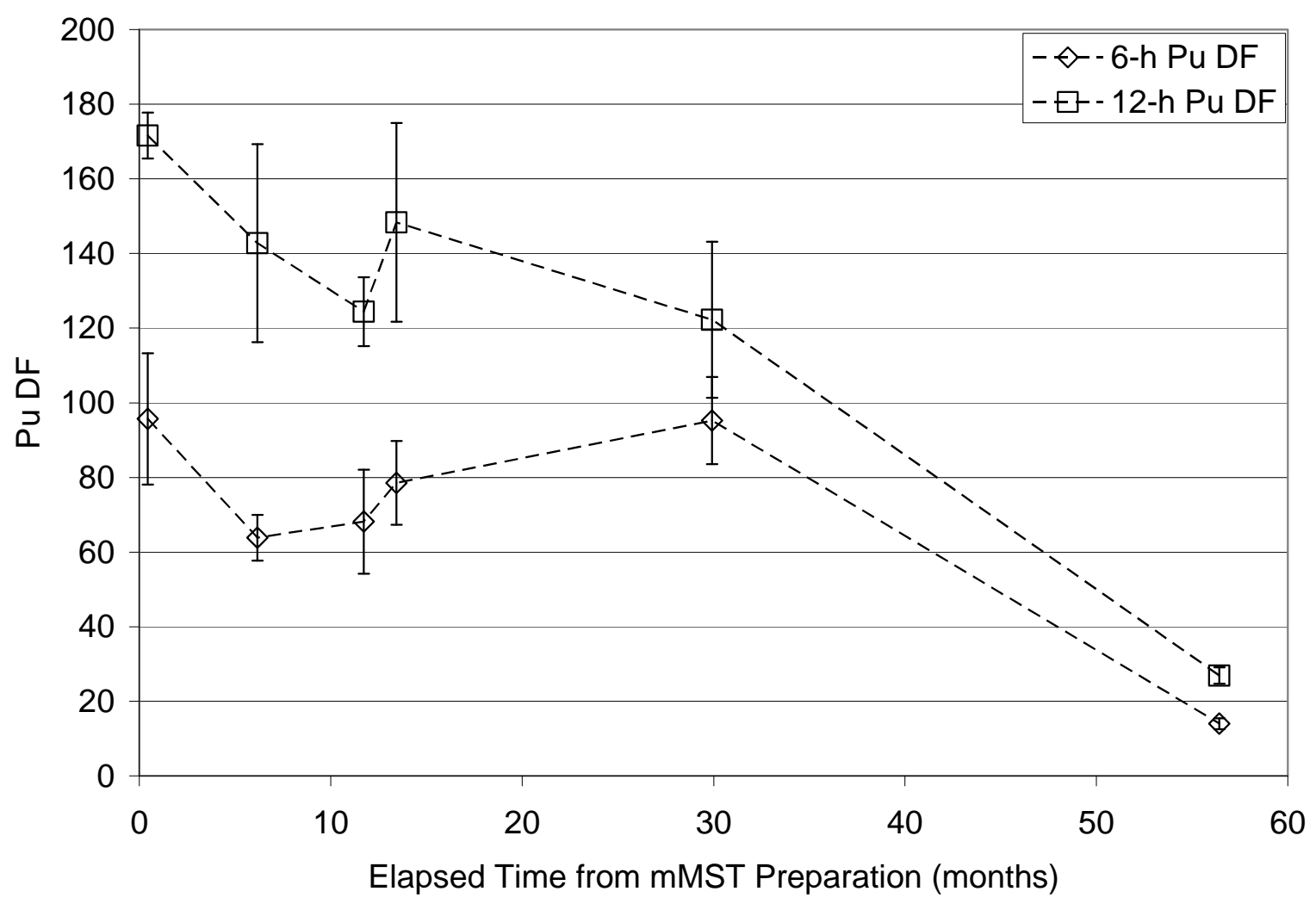

Figure 7. 6-h (diamonds) and 12-h (squares) Pu DFs for LS-2 as a function of elapsed time since preparation. 


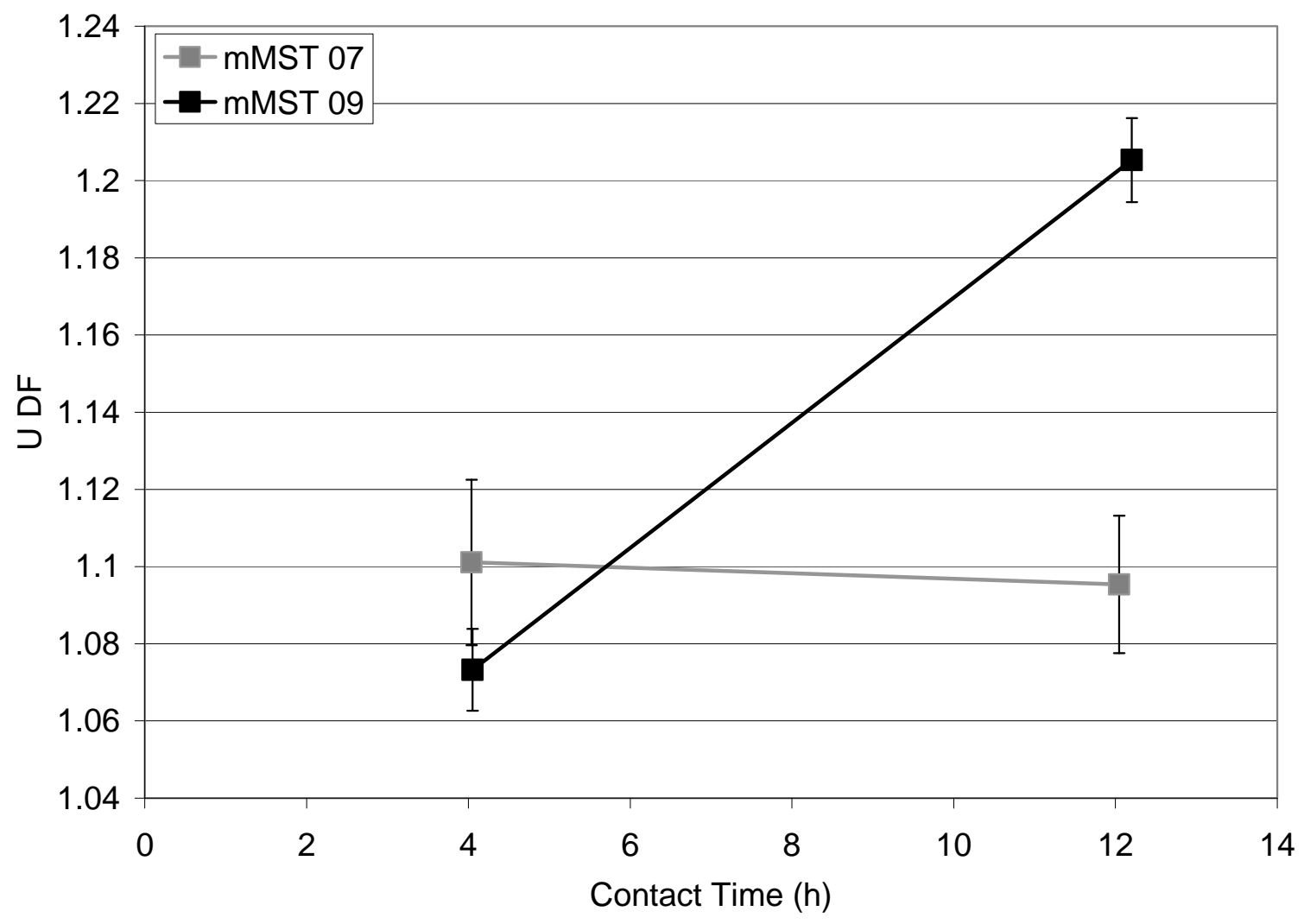

Figure 8. Uranium decontamination factors for mMST (Optima 06-QAB-0139) measured in October 2007 (gray) and in December 2009 (black). 